\title{
7-1993
}

\section{A curriculum based on systems theory.}

\author{
Ruth L. Schemm \\ Thomas Jefferson University \\ Mary Corcoran \\ Thomas Jefferson University \\ Ellen Kolodner \\ Thomas Jefferson University \\ Roseann C Schaaf \\ Thomas Jefferson University
}

Follow this and additional works at: https://jdc.jefferson.edu/otfp

Part of the Occupational Therapy Commons

Let us know how access to this document benefits you

\section{Recommended Citation}

Schemm, Ruth L.; Corcoran, Mary; Kolodner, Ellen; and Schaaf, Roseann C, "A curriculum based on systems theory." (1993). Department of Occupational Therapy Faculty Papers. Paper 26. https://jdc.jefferson.edu/otfp/26

This Article is brought to you for free and open access by the Jefferson Digital Commons. The Jefferson Digital Commons is a service of Thomas Jefferson University's Center for Teaching and Learning (CTL). The Commons is a showcase for Jefferson books and journals, peer-reviewed scholarly publications, unique historical collections from the University archives, and teaching tools. The Jefferson Digital Commons allows researchers and interested readers anywhere in the world to learn about and keep up to date with Jefferson scholarship. This article has been accepted for inclusion in Department of Occupational Therapy Faculty Papers by an authorized administrator of the Jefferson Digital Commons. For more information, please contact: JeffersonDigitalCommons@jefferson.edu. 


\section{A Curriculum Based on Systems Theory}

\author{
Ruth Levine Schemm, Mary Corcoran, \\ Ellen Kolodner, Roseann Schaaf
}

\author{
Key Words: education $\bullet$ human activities and \\ occupations
}

This paper describes an entry-level curriculum based on systems theory that was designed to promote integraled thinking and a shared image of practice among all of the members of an educational community that included students, faculty, and clinicians. Initiated in 1983, the program integrates occupational therapy theory, critical thinking, and knowledge about person-environmenal transactions with traditional medical, biological, psychological, and sociological course work to create a unique educational experience. The curriculum model is based on a spiral learning process that encourages integrated thinking. Furthermore, all concepts are systematically lied to the occupation core, the central theme of the program. Fieldwork is used to reinforce ideas presented in the classroom and features discrete learning experiences where students demonstrate their integration of knowledge and skills.

In an evaluation of the program, responses fiom 78 clinician, 51 alumni, and 132 student questionnaires; feedback from 132 fieldwork supervisors; and longitudinal data from 33 alumni confirmed that graduates are critical thinkers ubo appreciate the diverse needs of clients while demonstrating an apprecialion for the curative effect of meaningful, goal-directed activities.

Ruth Levine Schemm, F(I), Ol'k i.. FAort, is Professor and Chailman, Department of Occupational Therapy, Thomas Jefferson University, College of Allied Health Sciences, 130 South 9th Street, Room 824, Philadelphia. Pennsylvania 19107.

Mary Corcoran, PhD. OTR., is Assistant Professor. Department of Occupational Therapy, Thomas Jefferson University, College of Allied Hcalth Sciences, Philaclelphia, Pennsylvania.

Ellen Kolodner, MSS, OTR 1.. FAOTA, is Director of Occupational Therapy, Magee Rehabilitation Hospital, Philadelphia, Pennsylvania.

Roseann Schaaf, MEci. OTR L. is Instructor, Thomas Jefferson University, College of Allied Health Sciences, Philadelphia, Pennsylvania.

This aricle was accepled for publication Warch 15.1993.
$\mathrm{T}$ Thirty years ago, Reilly challenged educators to place occupation at the core of professional education (Reilly, 1958, 1966, 1969, 1971) using systems theory as the structure or framework for learning (Rogers, 1983). Systems theory offered an organizational structure in which students could order ideas, starting with basic concepts, and build understanding so that seemingly diverse units of information were unified into an integrated approach to individual care. Reilly maintained that an occupational therapy conceptual foundation must unify knowledge from science and humanities and promote communication among specialists (von Bertalanffy, 1968; Boulding, 1968)

This paper describes a curriculum developed 10 years ago at Thomas Jefferson University in Philadelphia with systems theory as the framerwork and occupation as the core curriculum concept. It includes the program mission, philosophy, goals, the use of systems theory as a curriculum organizer, course offerings by semester, the use of fieldwork as a bridge linking didactic and clinical work, and the curriculum evaluation and outcome measurement process.

\section{Overview of the Program Mission, Philosophy, and Goals}

Curriculum planning begins with the program mission, philosophy, and goals. These ideas set the direction of other efforts and offer a context for further program planning.

\section{Mission}

The 'Thomas Jefferson University mission is

\begin{abstract}
ro educare qualified physicians, nurses, biomedical scientists and alled heallh personncl; to expand our understancling of human beings and their environment... through research; and wo provide and promote health senvices as a basis for clinical celucation. 'To pursue these purposes with balance and clistinction, the Universi1) fosters a medically: biologicalls, and health sriented community of scholats. reachers, and clinicians who are dedicated to high unaline patiene senvices based on expanding knowleclge and unckrstanding of human beings. (College of Gratuace Siudies. $1992-93$, p. 9$)$
\end{abstract}

On the basis of these university values and goals, the Department of Occupational Therapy curriculum mission emphasizes the knowledgeable and skilled practitioner who is able to function in medical as well as communitybased organizations. Rogers (1982a) captured the essential characteristics of this person when she described the "inquisitive practitioner" as a curious problem-solver who uses the occupational therapy process, research, and his or her own abilities to deliver quality client services.

Scholarly practitioners posscoss incellecual curiosity and are critical. reflective thinkers. They see knowledge as the ferundation of practice, and ther view incluiry as the means of organizing. adcling 10. and refining knowledge. They recognize that it is nor conough to treat clients without also seeking better ways of trearing them. 
and therefore they scrutinize routine practices and procedures (Rogers, 1982a, p. 4)

The curriculum planning began with the faculcy who wanted to teach students to think critically and analytically about the occupational nature of humans. An advisory committee composed of faculty from other programs, practitioners, and employers soon clarified that the most important characteristic of an entry-level graduate was the ability to solve problems and give and receive feedback. Recent findings in clinical reasoning research reinforce these ideas by emphasizing the importance of critical thinking and problem solving rather than promoting the memorization of predetermined treatment approaches (Benner, 1984; Burke, 1983; Burke \& DePoy, 1991; Fleming, 1991; Mattingly, 1991; Parham, 1987; Schön, 1983). Thus, the graduate who thinks critically about clinical problems demonstrates the qualities of a reflective, inquisitive practitioner rather than those of a technician (American Occupational Therapy Association [AOTA], 1986)

\section{Pbilosopby}

A broad program philosophy was used to integrate the diverse ideas of curriculum planners and to shape all curriculum and teaching methodology decisions. The Jefferson occupational therapy program planners recognized that a philosophical statement could unify different practice approaches, creating an educational program that cmphasized core concepts and beliefs. Toward this end, it seemed best to place occupation at the core of the curriculum while reaching back to the early tenets of practice: (a) mind-body unity and (b) consideration of the person in the context of his or her environment.

\section{Occupation as a Core Concept}

Occupational science is emerging as one of the fundamental knowledge bases that should be taught to students during their professional education (Yerxa et al., 1990). A curriculum with an occupational core integrates concepts from biological, medical, and social sciences as well as knowledge from the humanities and applied fields with information on the occupational nature of humans (Reilly, 1969). Given the complexity and breadth of such a core, systems theory becomes an important conceptual tool that offers a framework for focusing student attention on the biopsychosocial nature of humans rather than on pathology

This approach is a departure from many of the curriculum planning ideas used as the foundation for other educational programs. During the Jefferson planning period, human growth and development, medical pathology (psychiatry, pediatrics, and physical dysfunction) and psychology (Maslow's Hicrarchy of Needs) were studied as conceptual frameworks. However, the Jefferson pro- gram planners were intrigued with Reilly's ideas and set out to operationalize them. In 1969 Reilly maintained that "challenging old values and reconstructing new ones, [sic] are necessary steps in furthering an independent professional identity" (p. 299). Thus, the design of entrylevel education is more than an organizational plan for making students learn facts and skills; it is the faculty's image of future practice. In this way, faculty have a potentially enormous influence on practict. Jantzen (1974) once described this potential influence as a geometric progression of ideas in that one faculty member teaches 50 students per year, and these students graduate and in turn become 50 practitioners who tcach many clients, students, and colleagues. Thus, Reilly's challenge to reconstruct our professional identity as based on the occupational nature of humans could be addressed by placing occupation at the core of the entry-level curriculum.

\section{Curriculum Goals}

Once the mission and philosophy were established, faculty developed an image of the graduate who was a knowledgeable and skilled professional with humanistic values, able to frame and solve problems. Eight curriculum competencies were developed to focus on issues involving the human condition, the health care system, persons, and treatment as well as professional development, therapists' roles and treatment settings, and clinical reasoning (see Appendix). Finally, students were required to assess personal attributes such as demonstrating self-knowledge and the ability to adapt to emerging situations and conditions.

The inclusion of clinical educators in this phase of planning guaranteed a cohesive curriculum in which agreement on desired outcomes was shared and learning structured toward achievement of those outcomes. At this time it was important to have a comprehensive understanding of the interplay between learner needs in a professional entry-level program and contemporary issues shaping the students' educational experience (Tyler, 1949). On the basis of such an understanding, learning experiences werc created by design, through use of structure in the classroom and clinic to stimulate the desired outcome behaviors in students. Furthermore, Jefferson curriculum planners wanted students to feel challenged and competent at the same time, which meant that novelty and repetition had to be carefully balanced.

\section{Program Description}

Using systems theory, the curriculum introduces concepts in a progressive spiral of Jearning first described by Bruner (1960). On the basis of Reilly's ideas (1958, 1966, 1969,1971 ), faculty developed a learning matrix with occupation at the core and all other knowledge presented as it relates to the occupational nature of humans (Rog- 
ers, 1984). The matrix creates a taxonomy of learning (see Figure 1). For example, because the students have pierequisite knowledge of anatomy and physiology, they study surface anatomy, which includes a laboratory where the muscular basis of motion is analyzed through real-life examples. Students decicle how someone with nerve damage can hold a pencil and how a person with paralysis can reach for a spoon. Because graduates have a solid foundation in systems theory, a vision of the underpinnings of the profession, and the ability to relate all knowledge to occupation, they would gain the ability to perform successfully both inside and outside the framework of medical practice.

Yerxa and Sharrot (1986) emphasized the importance of humanism in occupational therapy education. These ideas were consistent with the faculty's shared image of practice, which focuses on occupation and expands beyond the limitations of medical and biological frameworks. Therefore, to ensure that students entered the program with a humanistic focus, preadmission learning was integrated with courses in the professional curriculum. Prerequisites are as follows:

- English - 6 semester hours

- Biology with Laboratory-6 semester hours

- Anatomy and Physiology - 6 semester hours

- College Math - 3 semester hours

- Introduction to Sociology - 3 semester hours

- Ethnic Sociology/Cultural Anthropology-3 semester hours

- Introduction to Psychology - 3 semester hours

- Developmental Psychology - 3 semester hours

- Abnormal Psychology-3 semester hours

- Electives-15 semester hours.

These prerequisites are designed to balance information that is fundamental to the occupational therapy process

\begin{tabular}{|c|c|c|c|}
\hline Levels & Biologic Domain & Psychologic Domain & Social Domain \\
\hline Social & & & $\begin{array}{l}\text { Tradition of values, meanings, } \\
\text { and technology which impact } \\
\text { occupation }\end{array}$ \\
\hline Symbolic & & $\begin{array}{l}\text { Values, goals, temporality, } \\
\text { interests and personal causation }\end{array}$ & $\begin{array}{l}\text { Impact of culture on personality } \\
\text { such as definitions of time, } \\
\text { cultural interests, values, and } \\
\text { so forth }\end{array}$ \\
\hline Iconic & $\begin{array}{l}\text { Brain as coordinator of } \\
\text { sensory and motor } \\
\text { information and as } \\
\text { infrastructure of images }\end{array}$ & $\begin{array}{l}\text { Complex network of images that } \\
\text { constitute an inner model of the } \\
\text { external world }\end{array}$ & $\begin{array}{l}\text { Skilled actions and performances } \\
\text { maintained in the group tradition }\end{array}$ \\
\hline Differentiated & $\begin{array}{l}\text { Differentiation and } \\
\text { specialization of nervous } \\
\text { and musculoskeletal } \\
\text { systems }\end{array}$ & $\begin{array}{l}\text { Differentiation of occupational } \\
\text { behaviors and their underlying } \\
\text { symbols and images over the } \\
\text { lifespan }\end{array}$ & $\begin{array}{l}\text { Divisions of labor and integration } \\
\text { of individuals in group }\end{array}$ \\
\hline Open & $\begin{array}{l}\text { Spontaneous, holistic, and } \\
\text { self-maintaining process } \\
\text { of sensory input and } \\
\text { motor output }\end{array}$ & $\begin{array}{l}\text { Spontaneous urge for activity as } \\
\text { organizing principle. Occupational } \\
\text { behavior as self-maintaining } \\
\text { output }\end{array}$ & $\begin{array}{l}\text { Organizations as self-maintaining } \\
\text { systems with input, output, } \\
\text { and throughput }\end{array}$ \\
\hline Cybernetic & $\begin{array}{l}\text { Feedback loops in the } \\
\text { nervous system }\end{array}$ & $\begin{array}{l}\text { Feedback regulation of skilled } \\
\text { action and social feedback } \\
\text { moditying self-concept }\end{array}$ & $\begin{array}{l}\text { Social feedback processes } \\
\text { regulating performance } \\
\text { of group members }\end{array}$ \\
\hline Clockwork & $\begin{array}{l}\text { Kinetics of movement } \\
\text { simple relexes }\end{array}$ & $\begin{array}{l}\text { Balance of work and play, } \\
\text { dynamics of life space }\end{array}$ & $\begin{array}{l}\text { Dyadic interaction and } \\
\text { group dynamics }\end{array}$ \\
\hline Framework & $\begin{array}{l}\text { Anatomy of the } \\
\text { musculoskeletal and } \\
\text { nervous systems }\end{array}$ & $\begin{array}{l}\text { Pattern of motives and symbols } \\
\text { which energize and organize } \\
\text { behavior }\end{array}$ & $\begin{array}{l}\text { Social roles and status within } \\
\text { group structure }\end{array}$ \\
\hline
\end{tabular}

Figure 1. Hierarchical knowledge in biopsychosocial domains. Reprinted with permision from Kielhofner, G. (1983). Health through occupation (p. 70). Philadelphia: F. A. Davis. 
with the faculty's desire to expose students to humanistic knowledge. Students can merge basic biological information with humanistic concepts and ready themselves for further personal and professional development.

\section{Systems Theory as a Curriculum Organizer}

As illustrated in Figure 1, the curriculum uses a matrix to systematically structure the learning experiences of students. The matrix reflects the work of Boulding (1968), an economist, who refined the ideas of a biologist, von Bertalanffy, to develop a framework to promote communication among scholars, who work in different fields. Reilly applied these ideas to occupational therapy education in a 1978 workshop held in Philadelphia, and Kielhofner (1983) and Rogers (1983) linked these ideas to practice. The matrix, which describes the hierarchical knowledge in biopsychosocial domains (Kielhofner, 1983; Reilly, $1958,1966,1969$ ), orders levels of knowledge (see Figure 1) and provides an organization for governing the relationships among the levels in the system. In the Jefferson educational program, the first level of the matrix combines preadmission learning with basic information on biological systems (e.g., surface anatomy, the development of reflexes, an overview of practice and medical pathology). As each semester unfolds, student learning progresses to include increasingly sophisticated social systems concepts. Multilaycred ideas that require integration of concepts for clinical reasoning, intervention planning, and research complete the spiral of learning. At the same time, clinical assignments progress in complexity, promoting student competence in skilled observation, critical thinking, problem solving, and occupation-based interventions. This spiral learning process is designed to guide student learning toward an integrated system of didactic and clinical experiences that is presented in the next section of this paper.

Fieldwork is an integral aspect of learning, linking theory and practice by highlighting various aspects of the occupational therapy process. In each of four clerkships (level I fieldwork), students demonstrate skills that reflect an integration of classroom knowledge and clinical abilities. The faculty member and clinical supervisor use assignments that strengthen the student's knowledge of the occupational therapy process: observation, evaluation, theory-based treatment intervention, and outcome measures. Traditional and nontraditional practicum sites offer experiences with a variety of populations, and students' assignments are rotated so each student works with persons of a variety of ages and disability areas. Assignments are holistic, generic, and applicable to a broad variety of sertings, ranging from traditional rehabilitation clinics to residences for the homeless. Communication with clinical educators is reinforced with site visits, telephone consultations, course outlines, specific assignment instructions, and clinical council meetings. For example, students are asked to evaluate a client who has deteriorated habits and roles rather than a person with a specific medical condition. Fach semester is described briefly below.

\section{First Semester}

In this semester, students gain the building blocks for subsequent semesters by studying the physical determinants of occupational performance. Surface anatomy includes the structures of the body as well as a laboratory that requires experience and visualization of the body in motion. Motor development examines the development of reflexes in depth, focusing on children. Medical pathology is a survey course that uses physiatrist-lecturers who describe musculoskeletal diseases and medical intervention. At the same time, an occupational therapist serves an important role as course coordinator. Clinical skills, such as walking and transferring a client, taking a blood pressure, making a resting splint, and measuring range of motion are introduced in a laboratory class. The domain of occupational therapy practice is discussed in an overview course that previews theory and practice, professional identity, and practice domains, ideas that will be repeated in other courses. Assignments in clinics where clients are chronically disabled further emphasize the content of this course through student participation in guided observations that require communication skills.

\section{Second Semester}

The second semester of the program focuses on the evaluation process, occupation as a central aspect of human behavior, and the cognitive, psychological, social, and neuromotor determinants of occupational performance. Neuroanatomy is taught by an occupational therapist who directs a laboratory using brain specimens with the assistance of occupational therapist laboratory demonstrators. Lecture material emphasizes the applied aspects of the neuroanatomy. In an occupations course and accompanying laboratory, students learn about the curative aspects of occupations, how to prescribe and analyze activities, and how to learn about and teach others selected occupations. Additionally, students learn to evaluate persons using the concepts of role and occupational dysfunction and to synthesize information gained through observation and evaluation in order to formulate professional treatment plans and goals (Christiansen, 1991; Rogers, 1982b; Rogers \& Holm, 1989; World Health Organization, 1980). Medical pathology focuses on neurological pathology and psychiatric dysfunction as an extension of the previous pathology course. A course on promoting client competence builds on the rescarch of White (1971) and Allen (1985) and requires an understanding of the development of cognitive and psychosocial abilities. Students apply their developing knowledge 


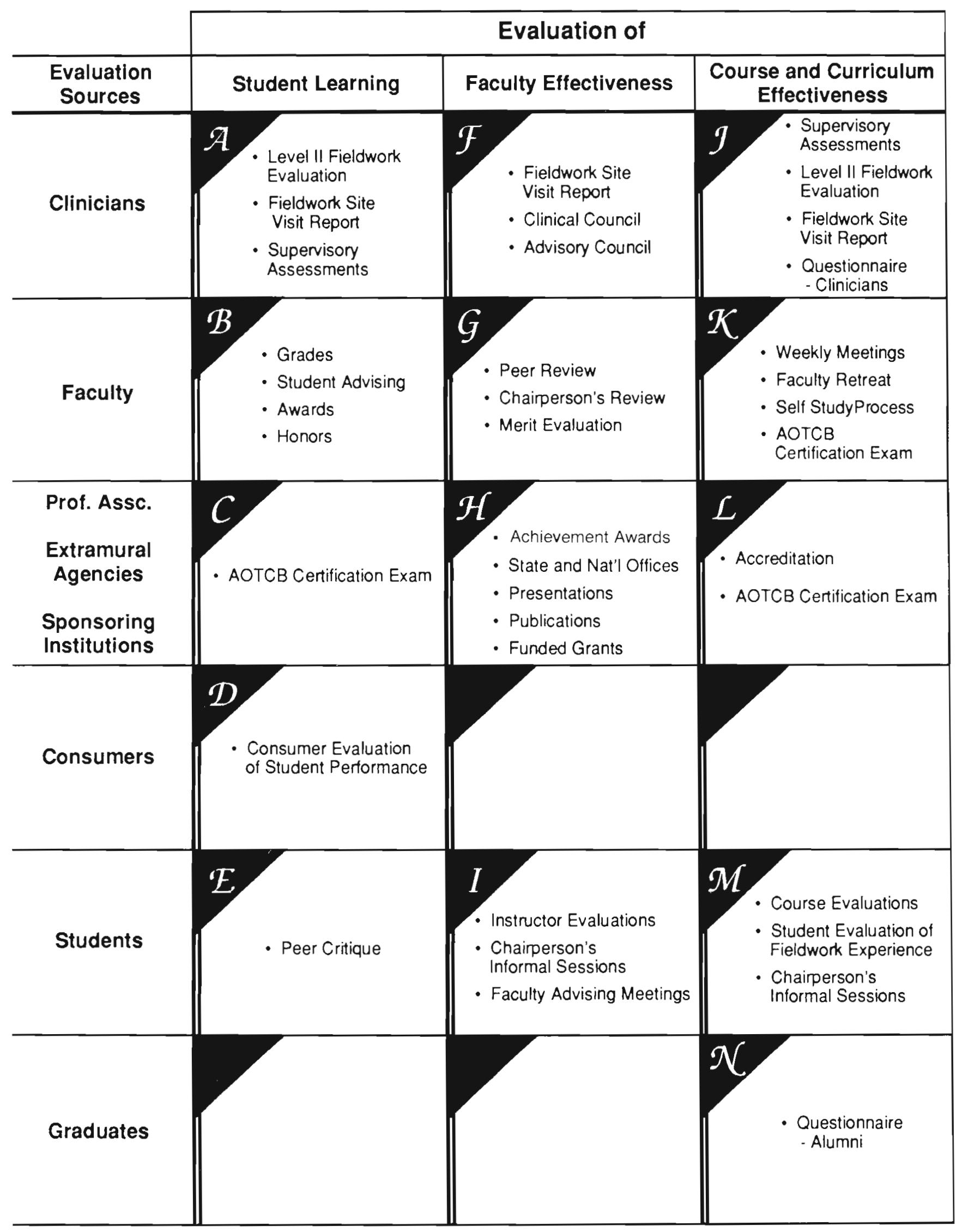

Figure 2. Thomas Jefferson University educational program evaluation. 
in their level I ficldwork as they are encouraged to think beyond the limitations of a pathological perspective for the chronically disabled person. The students' clinical assignments during this semester are focused on the evaluation process, emphasizing evaluation of occupational function and dysfunction.

\section{Third Semester}

Moving up the matrix, this semester focuses on the student's development of a systematic approach to client's occupational dysfunction using theory-based ideas that reflect the treatment context. Clinical intervention is presented from the generic perspective presented in AOTA documents such as Entry Level Role Delineation (AOTA, 1990), the Hierarchy of Competencies (AOTA, 1984), and Uniform Terminology-Second Edilion (AOTA, 1990). A]though specific strategies used in traditional, specialty, and emerging practice arenas are examined, they are offered as a means to carry out occupation-directed goals. Specific hands-on skills are developed in the interventions laboratory. Further experience is offered in a course devoted entirely to environmental aclaptations, where students are assigned a chronically disabled client and visit him or her 7 to 10 times. Using ideas grounded in phenomenology, students are expected to promote the person's competence through environmental adaptations that are culturally relevant. A course in occupational therapy history examines the origin and evolution of practice and encourages students to trace a clinical issue over a decade. In a theory course, students survey occupational therapy theories, compare major theories and models, and link theory to research and quality clinical intervention. Management, public relations, program development, planning, and finding new outlets for service provision are presented in the administration course. The level I fieldwork is linked to the theory and intervention courses and students develop theory-based interventions that are appropriate for a given facility.

\section{Fourtb Semester}

The final semester of didactic work features courses in advanced, specialized intervention strategies, research methodology, social role development, and several electives. The advanced intervention course is based on clinical reasoning concepts and reinforces treatment and documentation in specialized, theoretically based programs that promote occupational functioning. The social roles course offers an opportunity for students to examine their own roles in a group and to learn how to treat clients in groups. The developmental approach features a full spectrum of client populations so students gain an integrated understanding of group treatment. Learning how to be a research consumer and promoting interest in research is offered in a research design course. The last level I fieldwork rotation provides an opportunity for the development of an integrated understanding of theorybased occupational therapy practice starting with evaluation and reinforcing stages of occupational therapy process.

\section{Level II Fieldwork.}

Level ll fieldwork or full-time clinical experiences follow the senior year. Students are first assigned to a chronic care setting, then to an acute care setting. Specific objectives for each experience are delineated on the corresponding course outline so students, faculty, and fieldwork educators share the same objectives. The student's transition to practice is addressed from professional and administrative perspectives in two seminars that were originally scheduled in the middle of the learning experience and were moved, 3 years ago, to the week preceding the fieldwork experience.

\section{Curriculum Evaluation}

Although the Jefferson curriculum was described by the first on-site accreditation team as "visionary," clinical faculty were still concerned about the effect of the occupation focus on graduates. For instance, some worried that students were shortchanged by the limited emphasis on medical and biological sciences. To address these concerns, an objective means was devised to measure the performance of Jefferson graduates with a qualitative and quantitative analysis of program effectiveness. Through a range of methodologies and perspectives, a composite understanding of program strengths and limitations was developed. Data collected from six primary sourcesclinicians, faculty, extramural agencies, consumers, students, and graduates - were organized in a matrix and used to evaluate student learning, faculty, and curriculum effectiveness (see Figure 2). Data collection methods combined traditional strategies used by most academic programs (cxamination scores, course evaluations, etc.) with clinician, alumni, student, and consumer questionnaires, and data from a college-wide longitudinal study. Furthermore, a thematic analysis of data from the clinician and alumni questionnaires revealed broader practice issues and provided faculty with a critical understanding of changes emerging in both the academic and clinical communities (Pendergast et al., 1991; Perry \& Lee, 1988). These newly emerging practice issues, such as the controversy concerning use of physical agent modalities, were used to interpret the results of the program evaluation and guide faculty discussions concerning curriculum changes.

In addition to analysis of quantitative and qualitative data, the cvaluation process involved both a formative (ongoing) and a summative approach. A formative evaluation process offers stakeholders (such as faculty, stu- 
dents, clinicians, and consumers) an opportunity to identify recommendations for change in evolving programs (Guba \& Lincoln, 1987). An example of a formative approach to evaluation involves the cliscussions that take place during regularly scheduled faculty meetings where both student and faculty performance is systematically discussed and assessed. On the other hand, summative evaluation methods, such as questionnaires and the American Occupational Therapy Certification Board (AOTCB) examination scores, are used to assess educational outcomes. Data from these instruments serve as an indicator of student performance and curriculum effectiveness for each academic year.

This comprehensive evaluation process was developed to generate information about the relationships among the curriculum design, curriculum implementation, and student performance. Specifically, the faculty wanted to know whether the systems perspective of the curriculum actually pronoted students' critical thinking about the occupational nature of humans. Several indicators of congruence among the systems theory curriculum design, curriculum implementation, and student performance were identified (see Table 1). For instance, one expected outcome of the systems theory curriculum design was to merge humanistic and biological information into treatment that consiclered the client as a whole person. As shown in Table 1, 98\% of clinicians surveyed commented that Jefferson students treat clients holistically. Table 1 presents data to support other indicators of congruence, including student, alumni, and clinician perceptions of Jefferson students' sense of positive correlation between theories taught didactically and their clinical

Table 1

Indicators of Congruence Among Curriculum Design, Curriculum Implementation, and Student Performance

\begin{tabular}{|c|c|c|}
\hline Indicators & $\begin{array}{c}\text { "Yes" } \\
\text { Response } \\
(\%)\end{array}$ & Dala Source \\
\hline $\begin{array}{l}\text { Perceives a posisive corre- } \\
\text { lation berween theory } \\
\text { and clinic }\end{array}$ & 95 & $\begin{array}{l}\text { Stuclent and alumni } \\
\text { questionnaires }\end{array}$ \\
\hline $\begin{array}{l}\text { Considers the clicint as a } \\
\text { whole person }\end{array}$ & 98 & Clinician questionmaire \\
\hline $\begin{array}{l}\text { Integrates theory with } \\
\text { practice }\end{array}$ & 98 & Clinician questionnatre \\
\hline $\begin{array}{l}\text { Inclividualizes reatment } \\
\text { plans }\end{array}$ & 97 & $\begin{array}{l}\text { Clinician and alumni } \\
\text { questionnares }\end{array}$ \\
\hline $\begin{array}{l}\text { Lnderstands the role of } \\
\text { the environment in } \\
\text { occupational functioning }\end{array}$ & 99 & $\begin{array}{l}\text { Clinician and alumni } \\
\text { questionnaires }\end{array}$ \\
\hline $\begin{array}{l}\text { Recognizes contribution } \\
\text { of research lo practice }\end{array}$ & 86 & $\begin{array}{l}\text { Clinician and alumni } \\
\text { questionnaires }\end{array}$ \\
\hline $\begin{array}{l}\text { Demonstrates effective } \\
\text { problem solving }\end{array}$ & 93 & $\begin{array}{l}\text { Clinician and alumn } \\
\text { questionnaires }\end{array}$ \\
\hline $\begin{array}{l}\text { Takes responsibility for } \\
\text { own continued learning }\end{array}$ & 96 & $\begin{array}{l}\text { Clincian and alumni } \\
\text { guestionnaires }\end{array}$ \\
\hline
\end{tabular}

"132 respondents, $100 \%$ responsc late.

b51 respondents, $40 \%$ response rate

c78 respondents, $31 \%$ response rate. application; integration of theory with practice; indiviclualized treatment planning; effective problem solving; sense of responsibility for continued learning; understanding of the role of the environment in occupational functioning; and recognition of research's contribution to development of the profession. As one surveyed clinician commented, "Jefferson graduates are effective observers who willingly share creative ideas that emphasize reinforcement of patient competence." Thus, the strengths of current student and alumni performance suggest that the design of the curriculum is effective in producing entrylevel occupational therapists who demonstrate critical thinking skills

The evaluation process also helped faculty to focus on areas that require attention, such as growing numbers of students with complex personal problems, and led to creation of a curriculum evaluator position. The curricuIum evaluator's primary responsibility is to take the time to collect, organize, and disseminate information on student performance inclicators, such as fieldwork supervisors' comments, to faculty, clinical educators, college administrators, and external evaluators. This ongoing method of evaluation includes a process to introduce topics for discussion during weekly faculty meetings and offers time to explore these topics, as well as newly emerging issues, in lepth during semiannual program evaluation retreats. To date, this continuing system for monitoring the effectiveness of the Jefferson program has been successfully integrated into a busy faculty agenda.

\section{Conclusion}

This paper offers a model for curriculum development that is applicable to both clinical and educational programs. The curriculum described here has been effective in promoting understanding of occupation, interactions between people and their environments, problem solving, and critical thinking. Students who are educated within this curriculum demonstrate reflective, critical thinking and problem-solving skills grounded in an appreciation of occupation as central to human behavior. The qualities are congruent with the curriculum planners' mission to educate inquisitive practitioners and use of systems theory as a philosophical foundation for entrylevel education.

\section{Appendix Curriculum Competencies}

The following is a list of the program terminal competencies with corresponding semester goals and courses.

\section{Competency 1: Describe the Human Condition From a Variety of Perspectives}

1.1 Recognize how disease disrupts individual lives

1.2 Examine how people with disabilities adapt to disabling conditions

1.3 Demonstrate how various theoretical perspectives con- 
rribute to an understanding of the human condition

1.4 Analyze psychosocial, environmentai, and clevelopmental conditions and their effect on human performance

Competency 2: Link Humanities, and Basic and Medical Sciences to the Occupational Core of Our Profession

2.1 Identify the structures of the brain, ncrvous and musculoskeletal systems

2.1.1 Locate the anatomical basis for movement

2.1.2 Analyze the mechanical basis for movement

2.2 Describe individual motor development

2.3 Demonstrate skill in observing normal and abnormal movement patterns

2.4 Explain the influence of motor behavior on human performance

2.5 Identify the specific pathological conditions that affect sclected aspects of human development and movement

2.6 Describe symptoms and etiology of selected major pathological disorders

2.7 Examine the neurodevelopmental continuum and how it affects learning in normal and abnormal development

2.8 Formulate an understanding using various theoretical perspectives of how phylogeny and ontogeny affect human performance in work, play, self-care, and rest

Competency 3: Describe the Complex Nature of Human Biopsychosocial Needs from a Systems Perspective

3.1 Describe the effect of the neuromuscular and musculoskeletal system on performance of occupations

3.2 Examine the neurodevelopmental continuum and how it affects learning in normal and abnormal development

3.3 Examine the oncological development of cognition, perception, and personality structure using various thenretical perspectives

3.4 Examine how persons with disabilities adape to their disabling conditions

3.5 Describe theoretically specific treatment programs

3.6 Develop treatment programs based on a holistic rationale that consider the ongoing interaction of person and their environments

Competency 4: Utilize Occu pations, Tasks, and Activities to Promote Health and Competence in Individuals and Their Caregivers

4.1 Define the occupational therapy domain of concern in relation to health promotion

4.2 Elicit patient or caregiver goals and utilize them to plan interventions that engage patient or caregiver participation and commitment to the therapeutic process

4.3 Identify specific pathological conditions that impair competence and occupational performance

4.4 Systematically observe and analyze patient and caregivel occupations

4.5 Identify the principles in occupational therapy theories that enhance competence and promote health

4.6 Utilize those theory-based interventions involving occupations, tasks, and activities to enhance competence and promore health in parients and caregivers

4.7 Understand the transactional nature of person, culrure, and environment and the influence of each upon role performance

4.7.1 Identify psychosocial, environmental and developmental factors that influence a patient or caregiver's performance

4.7.2 Demonstrate proficiency in modifying occupations
4.7.3 Design and introduce culturally relevant adaptations to enhance patient or caregiver competence 4.7.4 Understand the teaching-lcarning process and apply to adapting the environment

4.8 Examine the development of the volitional and habituacion subsystems and their relationships to the performance subsystems

4.9 Assess individual behavior in terms of the volitional, habituation and performance subsystems

Competency 5: Demonstrate Entry-level Clinical Proficiency in All Aspects of the Occupational Therapy Process

5.1 Analyze psychosocial, environmental, and developmental conditions and their effect on human performance considering work, self-care, and play

5.2 Evaluate individual performance in work, self-care, and play

5.3 Demonstrate understanding of theoretical rationale for the selection of tratment techniques

5.4 Select and implement appropriate treatmont to promote inclividual performance and quality of life

5.5 Perform the following selected techniquics:

5.5.1 Interview individuals and their caregivers

5.5.2 Evaluate patient strengths and weaknesses using observation and appropriate instruments

5.5.3 Appropriately position, ambulate, and transfer individuals during treatment

5.5.4 Construct splints and equipment if indicated

5.5.5 Measure appropriate body functions and actions

5.5.6 Document obscrvations of individual capacities and limitations in concise, goal-clirected statements

5.5.7 Design and construct culcurally relevant adaptations to modify the influence of the environment on performance

5.6 Establish holistic treatment goals and plans based on the individual's unique incerests and needs in light of specific pathology and culture

5.7 Compare and contrast appropriate occupational therapy intervention for chronically disabled inclividuals

5.8 Apply entry-level knowledge and skills during treatment

5.9 Apply clinical reasoning concepts in goal-setting and treatment planning

5.10 Faciliate individual participation and investment in the therapeutic process

5.11 Apply entry-level knowledge and skills in the clinical setcing

\section{Competency 6: Understand the Relationship Between} Research, Theory, and Treatment

6.1 Utilize clinical reasoning concepts in goal-setting and treatment planning

6.2 Use theory as a framework to understand indiviclual response to treatment

6.3 Inderstand how research and theory are linked to improved clinical practice and research

6.4 Demonstrate the ability to formulate clinically relevant research questions based on practice concerns

6.5 Understand the principles of clinical research

6.5.1 Understand the importance of using standardized assessment tools and standarlized procedures in clinical research

6.5.2 Select and implement appropriate research methodology to address clinical researcin questions

6.5.3 Design appropriace reatment protocols and understand the importance of efficacy studies 
6.5.4 Identify and utilize appropriate qualitative and quantitative data collection techniques

6.6 Understand the responsibilities of an occupational therapist member of a research team

Competency 7: Integrate Occupational Therapy Professional Values and Attitudes that are Implicit in a Variety of Occupational Therapists' Roles Including Clinician, Educator, Administrator, Researcher, Clinical Specialist, and Master Clinician

7.1 Examine the socialization process of a developing occupational therapist

7.2 Analyze personal response to clinical issues and demonstrate ability to use self therapeutically

7.3 Understand the professional standards and ethics

7.4 Discuss the importance of the supervisory process

7.5 Demonstrate appropriate professional behaviors and atcitucies

7.5.1 Demonstrate individual responsibility for continued learning

7.5.2 Recognize the value of documentation and validation of occupational therapy practice through research, publication, and program evaluation

7.6 Participate in the promotion of occupational therapy through professional organizations, governmental bodjes, and human service organizations

7.7 Understand the structure and function of local, state. national and international professional organizations

Competency 8: Demonstrate Entry-level Management Competencies Required to Adapt and Develop in a Complex and Changing Environment

8.1 Demonstrate an unclerstanding of governmental regulation and fiscal policies as they affect the provision of occupational therapy services

8.2 Identify methods for evaluating occupational therapyser vices including quality assurance and program evaluation

8.3 Formulate and monitor a bucket

8.3.1 Oreler supplies and equipment

8.4 Prepare and follow policies and procedures and job (lescriptions

8.5 Maincain equipment

8.5 Describe needs assessment, program planning, program development, strategic planning, market-based planning, and management information sistems

8.6 Describe various theorics of personnel management as they apply to occupational therapy assistants, staff occupational therapists, aides, and volunteers

8.6.1 Ielentify the importance of the supervisony process

8.7 Iclentify emerging arenas for occupational thexapy practice and iclentify strategies for solving organizational problems

8.8 Demonstrate understanding of safecy precaurions and techniques

\section{References}

Allen, C. (1985). Occupational therapl for psycbiatric diseases: Weasurement and managenten of cognilive disahilities. Boston: Little, Browin.

American Occupacional Therapy Association (1990). Ent/n level role detimeation for registered occupational therapists and certified occupational therapy' assistanls. Rockville, MD

American Occupational Therapy Association (1984). Hierarchy of comperencics relaring to the use of stanciardi\%ed instru- ments and evaluation techniques by occupational therapists. American Journal of Occupational Therapy, 38, 803-804. American Occupational Therapy Association. (1986). OCcupational herapy education: Target 2000 Proceedings. Rockville, MD: Author.

American Occupational Therapy Association. (1990). Uniform teminology for occupational therapy-second edition Rockville, MD: Author.

Benner, P. (1984). From novice to expert: Excellence and power in clinical practice. Reading, MA: Addison-Wesley.

Boulding, K. (1968). General systems theory: The skeleton of science. In Buckley, W. (Ed.), Modem systems research for the bebavioral scientist. Chicago: Aldine

Bruner, J. S. (1960). The process of education. Cambridge, MA: Harvard University press

Burke. J. P. (1983). Defining occupation: Importing and organizing interdisciplinary knowledge. In Kielhofner, G. (Ed.), Healtb tbrough occupation (pp. 125-138). Philadelphia: F. A. Davis.

Burke, J. P., \& DePoy, I. (1991). An emerging view of mastery, excellence, and leadership in occupational therapy practice. American Journal of Occupational Therapy, 45, 1027-1032.

Christiansen, C. (1991). Occuparional therapy: Intervention for life performance. In Christiansen, C. \& Baum, C. (Eds.), Occupational tberapl: Ouercoming buman performance deficits (pp. 3-44). Thorofare, NJ: Slack.

College of Graduate Studies. (1992-93). Thomas Jefferson ('niversill: Philadelphia: Thomas Jefferson University.

Fleming, M. (1991). The therapist with the three-track mind. American Joumal of Occupational Therapy, 45. $1007-1014$.

Guba, F., \& Lincoln, Y. (1987). Effective evalualion. Newbury Park, CA: Sage

Jantzen, A. C. (1974). 1973 Eleanor Clarke Slagle lectureAcadiemic occupational therapy: A career specialty. American Jounal of Occupational Therapl: 28(2), 73-81.

Kielhofner, G. (1.983). A paradign for practice: The hierarchical organization of occupational therapy knowwedge. In Kielhofner; G. (Ed.), Health through occupation (pp. 55-91). Phila. delphia: F. A. Davis

Mattingly, C. (1991). 'l'he narrative nature of clinical reasoning. American journal of Ocupalional Therapy', 45, 998-105.

Parham, D. (1987). Nationally Speaking-Toward professionalism: The reflective therapist. American Joumal of Occupalional Therapl: 41. 555-561.

Pendergast, N. D., Arrateig, L. M., Meyers, S. K., Edwards, E., Schwartrberg, S. L., \& Bailey, D. (1991). Program evaluation in the academic setting. Occupational Therapy Practice. 2(2). $61-73$.

Periy, J. \& Lee, C. E. (1988, Fall). Model for curriculum evaluation. Joumal of Pbisical Therapy Education, 13-17.

Rcilly, M. (1958). An occuparional cherapy curriculum for 1965. American Joumal of Occupational Therapj; 12. $293-299$

Reill, M. (1966). A psychiatric occupational therapy program as a teaching model. American Journal of Occupational Therapl' 20(2), 61-67.

Rcilly, M. (1969). The educational process. American yournal of Occupational Therapl: 23. 299-307.

Reilly, M. (1971). Occupational therapy: A historical perspective: The modernization of occupational therapy. American Jommal of Occupational Therapy', 25, 243-246

Reilly, M. (1978). Curriculum planning in occupational theraps: Workshop sponsored by Department of Occupational Therapy, Temple Lniversity, Philadelphia, PA.

Rogers, J. C. (1982a). Eulucating the inguisitive practitionet 
Occupational Therapy Joumal of Research, 1(2), 3-11.

Rogers, J. C. (1982b). The study of human occupation. In Kielhofner, G. (Ed.), Heallh tbrough occupation (pp. 93-124). Philadelphia: F. A. Davis.

Rogers, J. C. (1983). Hleanor Clarke Slagle leccure-1983. Clinical reasoning: The ethics, science and art. American fournal of Occupational Therapy, 37, 601-616.

Rogers, J. C. (1984, March). Curriculum planning based on matrix design. Consultation with Department of Occupational Therapy faculty. Thomas Jefferson University, Philadelphia.

Rogers, J. C., \& Holm, M. B. (1989). The therapist's thinking behind functional assessment I. In Royeen, C. (Ed.), AOTA Self Study Series, Assessing Function (Lesson 1). Rockville, MD American Occupational Therapy Association.

Schön, D. (1983). The reflective practitioner: How professionals think in action. San Francisco, CA: Jossey-Bass.

Tyler, R. W. (1949). Basic principles of curriculum and instruction. Chicago: University of Chicago Press.

von Bertalanffy, L. (1968). General system theory-A critical review. In Bucklev, W. (Ed.), Modem systems research for the behavioral scientist. Chicago: Alcline.

White, R. (1971). The urge toward competence. American Joumal of Occupational Therapy, 25, 271-274.

World Health Organization (1980). International classification of impairments disabilities, and bandicaps. Geneva, Switzerland: Author.

Yerxa, E. J., Clark, F., Frank, G., Jackson, J., Parham, D., Pierce, D., Stein, C., \& Zemke, R. (1990). An introduction to occupational science, a foundation for occupational therapy in the 21 st century. Occupational Therapy in Heallb Care, 6(1), $1-17$.

Yerxa, E. J., \& Sharror, G. (1986). Liberal arts: The foundation for occupational therapy education. American Joumal of Occupational Therapy, 40, 153-159.

\section{Cordelia Myers Writer's Award}

The American Occupational Therapy Association is pleased to announce that Loree $A$. Primeau has been chosen to receive the Cordelia Myers Writer's Award for the 1992 AJOT volume year. Her paper, "A Woman's Place: Unpaid Work in the Home," published in the November issue, was considered by the AJOT Editorial Board members to be a strong piece of professional writing by a first-time contributor to the AJOT during the 12-month period.

The AJOT Editorial Board and staff extend their congratulations to Loree A. Primeau. 